\title{
Two new species of Rineloricaria (Siluriformes: Loricariidae) from the rio Iguaçu basin, southern Brazil
}

\author{
Leonardo F. S. Ingenito ${ }^{1,2}$, Miriam S. Ghazzi ${ }^{1}$, Luiz F. Duboc ${ }^{2}$ and Vinícius Abilhoa ${ }^{2}$
}

\begin{abstract}
Rineloricaria langei and $R$. maacki, new species, are described from upper and middle regions of the rio Iguaçu basin, a left bank tributary of the rio Paraná basin, southern Brazil. Rineloricaria langei has narrow body and is similar to R. quadrensis, which is found in coastal rivers of Rio Grande do Sul State and is distinguishable by several morphometric characters. Rineloricaria maacki is distinguishable from all other congeners by the shape and extension of the naked area of the ventral region of pectoral girdle and other morphological characters. The presence of a naked region on the abdominal surface is shared with other species from the rio Paraná and rio Uruguay basins and coastal drainages from southeastern and southern Brazil. This may indicate a close phylogenetic relationship among these species. Similarities between the two new species and species from the aforementioned drainages also suggest close biogeographic relationship between the Paraná basin and other Brazilian coastal Atlantic drainages throughout the rio Iguaçu basin.
\end{abstract}

Rineloricaria langei e $R$. maacki, espécies novas, são descritas para os cursos médio e alto da bacia do rio Iguaçu, tributário esquerdo do sistema do rio Paraná, sul do Brasil. Rineloricaria langei tem o corpo estreito e é semelhante a $R$. quadrensis, que ocorre nos rios costeiros do estado do Rio Grande do Sul, da qual distingui-se por características morfométricas. Rineloricaria maacki distingui-se de todas as suas congêneres pela forma e extensão da área nua da região ventral da cintura peitoral e outras características morfológicas. A presença de uma região nua na superfície ventral de $R$. maacki é compartilhada por outras espécies das bacias dos rios Paraná e Uruguai, e das drenagens costeiras do sudeste e sul do Brasil. Isto pode indicar uma proximidade filogenética entre estas espécies. Semelhanças entre as duas espécies novas e espécies das bacias supracitadas também sugerem um relacionamento biogeográfico próximo entre a bacia do Paraná e os rios costeiros brasileiros através da bacia do rio Iguaçu.

Key words: Ostariophysi, Loricariinae, Neotropical Region, Rio Paraná basin, Systematics.

\section{Introduction}

Rineloricaria Bleeker includes 32 valid species inhabiting the rio Paraná basin, rio Uruguay basin, and coastal Atlantic rivers from eastern Brazil to Uruguay (Ferraris, 2007; Ghazzi, 2008; Rodriguez \& Reis, 2008). The genus is considered one of the most species-rich within the Loricariinae. Species of Rineloricaria occurs in a great variety of aquatic environments, and has been recorded from relatively polluted waters (Reis \& Cardoso, 2001; Flores-Lopes et al., 2001).

Despite the diversity and widespread distribution of the genus, the available descriptions are old and incomplete. In addition, the absence of types of some species, including Rineloricaria lima (Kner) and $R$. cubataonis (Steindachner)
(Isbrücker, 1979), intraspecific variation of some characters, and the existence of many undescribed species, render Rineloricaria as one of the most complex and poorly understood genera of the subfamily (Reis \& Cardoso, 2001). This situation is made worse by the fact that the only revision of the genus was performed more than a century ago by Regan (1904) as part of a comprehensive study of the Loricariidae, which had a very different composition at that time.

Isbrücker et al. (2001) revalidated Hemiloricaria Bleeker and created two new genera (Fonchiiichthys Isbrücker \& Michels and Leliella Isbrücker) in order to allocate many species of Rineloricaria based only on sexual dimorphism differences. Such decision was not adopted by Ferraris (2003), who kept 47 species in Rineloricaria. More recently, Ferraris (2007)

${ }^{1}$ Setor de Ictiologia, Departamento de Vertebrados, Museu Nacional (MNRJ) - UFRJ, Quinta da Boa Vista, 20940-040 Rio de Janeiro, RJ, Brazil.1fsi@uol.com.br; msghazzi@yahoo.com.br

${ }^{2}$ Grupo de Pesquisas em Ictiofauna (GPIc), Museu de História Natural Capão da Imbuia (MHNCI), Rua Prof. Benedito Conceição 407, 82810-080 Curitiba, PR, Brazil.1fduboc@uol.com.br; vabilhoa@uol.com.br 
in his siluriform catalog has revalidated the genera Hemiloricaria and Fonchiiichthys accepting the composition originally proposed by Isbrücker et al. (2001), however, without justifying his decision. Later, Covain \& Fisch-Muller (2007) published a revisionary study of the genera of the subfamily Loricariinae pointing out that the characteristics proposed by Isbrücker et al. (2001) to validate Fonchiiichthys, Hemiloricaria and Leliella were insufficient to diagnose those genera, and then, considered them as junior synonym of Rineloricaria. Rodriguez \& Reis (2008) accepted part of the phenetic groups proposed by Isbrücker et al. (2001) and distinguished Rineloricaria from Hemiloricaria by having wide body ( $v s$. narrow body), dorsal caudal-fin rays not prolonged in a filament, except by some species (vs. dorsal and ventral rays produced in a filament), abdomen variably covered with platelets ( $v s$. abdomen completely covered), typically a uniform body color pattern with five darker bands ( $v s$. very spotted dark color pattern), and sexual dimorphism where males have hypertrophied odontodes on the cheeks and the pectoral-fin rays ( $v s$. hypertrophied odontodes on the top of head to the predorsal area, on the cheeks and the pectoral-fin rays). The two species described in this paper and $R$. nigricauda (Regan), widely distributed in the rio Paraíba do Sul on the Rio de Janeiro State, exhibit the characteristics of the genus Rineloricaria as reported by Rodriguez \& Reis (2008). Because that, $R$. nigricauda was not considered in the genus Hemiloricaria like treated by Isbrucker et al. (2001), Ferraris (2007) and probably by Rodriguez \& Reis (2008) due to omission of this species in the text.

Recent studies about the ichthyofauna from rio Iguaçu basin revealed the presence of three or four species of Rineloricaria in that basin (Reis \& Cardoso, 2001; Vitule \& Abilhoa, 2003; Ingenito et al., 2004). In this study two of these species of Rineloricaria are described from the upper and middle/lower courses of rio Iguaçu drainage (sensu Ingenito et al., 2004).

\section{Material and Methods}

Morphological measurements were made point-to-point, to the nearest $0.1 \mathrm{~mm}$ with digital calipers, on the left side of the specimens whenever possible. Morphometric and meristic data followed Reis \& Cardoso (2001), plus counts of vertebrae and ribs, which were taken from cleared and doublestained specimens prepared according to the methodology proposed by Taylor \& Van Dyke (1985). Head depth was measured at the anterior margin of the parieto-supraoccipital bone. Plate nomenclature follows Schaefer (1997). Number of lateral plates was counted at the mid-ventral series. Counts are presented in the text followed by their frequency in parenthesis. An asterisk indicates counts for the holotype. Vertebral counts include the fused Weberian complex, counted as five elements, and the compound ural centrum, counted as one element. Specimens of less than $50 \mathrm{~mm}$ of standard length (SL) were not used for morphometric and meristic data. Pro- portions of head structures are expressed as percent of head length (HL).

The examined specimens are deposited in the fish collection of the Academy of Natural Science, Philadelphia (ANSP); Natural History Museum, London (BMNH); Instituto Fundacion Miguel Lillo, Tucuman (FML); Museu Anchieta, Porto Alegre (MAPA); Museu de Ciências e Tecnologia da Pontifícia Universidade Católica do Rio Grande do Sul, Porto Alegre (MCP); Museu de História Natural Capão da Imbuia, Curitiba (MHNCI); Museu Nacional, Rio de Janeiro (MNRJ); Museu Paraense Emílio Goeldi, Belém (MPEG); Museu de Zoologia da Universidade de São Paulo, São Paulo (MZUSP); Naturhistorisches Museum, Vienna (NMW); Núcleo de Pesquisas em Limnologia, Ictiologia e Aqüicultura da Universidade Estadual de Maringá, Maringá (NUP); Departamento de Zoologia da Universidade Federal do Rio Grande do Sul, Porto Alegre (UFRGS). All examined specimens are ethanol preserved, except those labeled with c\&s, which indicates cleared and double stained specimens and are preserved in glycerin.

\section{Rineloricaria langei, new species}

Figs. 1-2

Rineloricaria sp.; Ingenito et al., 2004: key, picture and comments (in part, only MHNCI 8937). [Picture shows a specimen from MHNCI 8937, but legend erroneously indicates MHNCI 9133].

Holotype. MCP 42506, male, 114.9 mm SL, Brazil, Paraná, Quatro Barras, rio Iraí, at Fazenda Moura-Daz, downstream Reservoir of

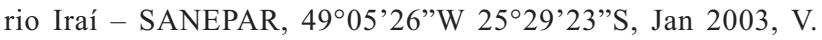
Abilhoa.

Paratypes. MCP 23459, 4 (1 male, 3 females), 71.7-116.5 mm SL. MHNCI 8937, 10 (1 male, 9 females), 51.7-111.9 mm SL. MNRJ 31157,5 (females, $1 \mathrm{c \& s}$ ), 81.1-106.2 mm SL. All specimens collected with the holotype.

Diagnosis. Rineloricaria langei can be distinguished from all species of the genus except $R$. catamarcensis, $R$. longicauda, $R$. maquinensis, $R$. misionera, $R$. nigricauda, $R$. quadrensis, and $R$. steindachneri by its narrow body (cleithral width $13.0-15.7 \%$ of SL; vs. $17.9-22.4 \%$ in $R$. aequalicuspis, $20.0-22.2 \%$ in $R$. anhaguapitan, $17.8-19.2 \%$ in $R$. anitae, $18.0-$ $21.8 \%$ in $R$. baliola, $16.0-19.1 \%$ in $R$. cadeae, $18.3-22.6 \%$ in $R$. capitonia, $17.7 \%$ in $R$. felipponei, $21.7-22.0 \%$ in $R$. jaraguensis, $17.1-20.6 \%$ in $R$. kronei, 19.1-20.6\% in $R$. latirostris, $16.8-19.3 \%$ in $R$. malabarbai, $18.3-24.0 \%$ in $R$. microlepidogaster, $17.9 \%$ in $R$. pareiacantha, $18.7-19.9 \%$ in $R$. pentamaculata, $18.3-23.6 \%$ in $R$. reisi, $17.6-19.6 \%$ in $R$. tropeira, $16.0-18.1 \%$ in $R$. sanga, $17.6-19.9 \%$ in $R$. setepovos, $16.6-19.9 \%$ in $R$. stellata, $15.8-21.4 \%$ in $R$. strigilata, $18.2 \%$ in $R$. thrissoceps, and $16.2-21.6 \%$ in $R$. zaina). Rineloricaria langei differs from $R$. catamarcensis, $R$. nigricauda and $R$. steindachneri by having the dorsal caudal ray not prolonged 


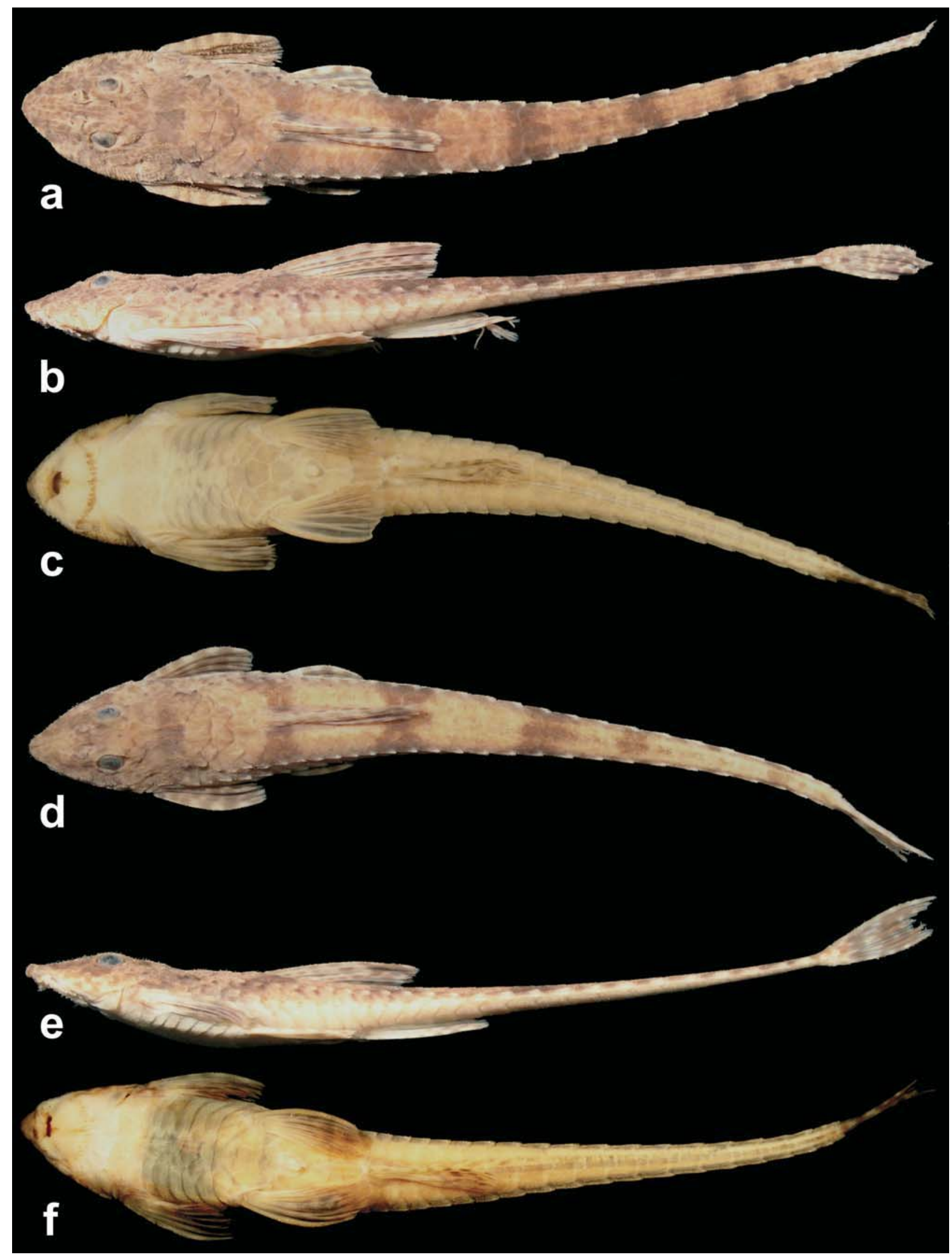

Fig. 1. Rineloricaria langei. a-c: holotype, male, MCP 42506, 114.9 mm SL; d-f: paratype, female, MCP 23459, 89.2 mm SL, rio Iraí, Quatro Barras, Paraná, Brazil. 
as a filament ( $v s$. dorsal caudal ray produced as a short filament). It is distinguished from $R$. quadrensis by having larger interorbital width (19.7-24.0\% vs. 18.5-19.3\% of HL) and longer dorsal-spine length (18.3-22.2\% vs. 17.4-18.6\% of SL); differs from $R$. longicauda by elliptical naked area at tip of snout, not reaching most anterior pore of the infraorbital sensory canal (vs. elongate naked area at tip of snout reaching the most anterior pore of the infraorbital sensory canal). In addition, $R$. langei can be easily distinguished from $R$. maquinensis (with abdomen almost naked) and $R$. misionera (with pectoral girdle not covered by plates) by abdomen and pectoral girdle completely covered by plates.

Description. Morphometric data in Table 1. Head and body deeply depressed. Head narrow in females and immature males, and broad in mature males. Body narrow. Body depth greatest at dorsal-fin origin. Head triangular in dorsal view. Dorsal profile of head convex from snout tip to anterior margin of parietosupraocciptal, thereafter slightly concave to posterior margin of first predorsal plate. Predorsal region straight. Trunk almost straight and gradually depressed from dorsal-fin origin to caudal-fin base. Ventral profile of body nearly straight from snout tip to anal-fin origin, then becoming more depressed towards caudal-fin base. Caudal peduncle depressed forming lateral keels with 12(1), 13(9), 14(8*), or 15 (2) coalesced plates from $29\left(6^{*}\right), 30(13)$ or 31(1) total lateral plates in middle series. Four lateral series of plates, mid-dorsal series absent. Abdomen and ventral region of pectoral girdle completely covered by plates, even in specimens smaller than $85.5 \mathrm{~mm}$ SL; plates almost reaching transverse line crossing through anterior margin of branchial openings. Ventral region of scapular girdle covered by several irregularly arranged platelets smaller than abdominal plates. One (2), two (1), three (16*) or four (1) series of abdominal plates, usually regularly distributed in adults. Abdominal plates of irregular shapes and sizes. Pre-anal plate present and anteriorly rounded by three polygonal plates. Lateral abdominal plates four (1), five ( $\left.9^{*}\right)$, six (9) or seven (1). Dorsal-fin base with five plate rows. Anal-fin base with two (8) or three (12*) plate rows. Two $(9)$ or three $\left(11^{*}\right)$ rows of plates between urogenital pore and anal fin. Plate counts on opposite sides of body usually different, except at dorsal- and anal-fin bases.

Top of head and parieto-supraocciptal wrinkled, with welldeveloped ridges. Ridges of parieto-supraocciptal diverging posteriorly in adult specimens and nearly parallel in young. Predorsal ridges parallel. Plates of first three mid-dorsal series with evident ridges. Upper edge of orbit raised. Postorbital notch shallow, short and wide, not surpassing one third of orbital diameter.

Head and body covered by small odontodes, somewhat more developed on top of head. Mature males with hypertrophied odontodes distributed only on lateral margins of head and dorsum of pectoral fin (Fig. 2). Snout tip with small elliptical naked area, not reaching most anterior pore of infraorbital ramus of sensory canal. Naked area of snout separated from upper lip by two to four series of inconspicuous odontodes. Lips well developed and covered by papillae; only one irregular row of papillae at anterior most area of upper lip. Two rows of inconspicuous papillae separating upper and lower lips. Maxillary barbel thin and shorter than orbital diameter. Notch present in lower lip. Teeth bicuspid with lateral cusp smaller than medial. Premaxilla with five (3), six (8), seven (7) or eight ( $\left.2^{*}\right)$ teeth. Dentary with five (2), six (6), seven (6) or eight $\left(6^{*}\right)$ teeth. Total number of vertebrae 33. Four ribs attached to vertebrae 7 to 10 .

Pectoral-fin rays seven $(i, 6)$; fin margin reaching pelvicfin origin when adpressed. Pelvic-fin rays six (i,5). Dorsal-fin rays eight $(i, 7)$; first ray shorter than head length; its origin located dorsal of pelvic-fin base. Anal-fin rays six (i,5). Caudal-fin rays 12 (i,10,i); its distal margin slightly concave; dorsal principal rays longer than ventral rays; in some specimens dorsal unbranched ray slightly elongated, extending distally less than one-third of orbital diameter and not prolonged as filament.

Color in alcohol. Ground color of dorsal surface of adults dark brown; specimens smaller than $85.5 \mathrm{~mm}$ SL light brown with small dark spots or vermiculated lines, mainly on snout. Dorsum of head with inconspicuous and scattered dark brown blotches, sometimes forming two weak longitudinal stripes extending from snout tip to anterior region of orbit, passing medially through nares. Longitudinal stripes usually join with greater number of chromatophores laterally and between eyes forming darker region on top of head. Five (4) or six (16*) dark brown transverse bars across body; first on dorsal-fin origin, second on distal margin of dorsal-fin rays, third immediately after vertical line passing through tip of anal-fin rays, fourth and fifth on caudal peduncle, and sixth at end of caudal peduncle, very close to base of caudal fin. Fourth and fifth transverse bars sometimes slightly wider. Fourth and fifth or fifth and sixth bars sometimes join into wider bar (forming five bars instead of six). Some pores of laterosensory system with dark chromatophores, more evident at anterior half of side of body. Color of sensory pores of head indistinct from background. Ventral surface of body pale yellowish. Some specimens with scattered chromatophores on median region of ventral surface of caudal peduncle, at anal-fin origin, and at base of pectoral and pelvic fins.

Fins yellowish with interradial skin hyaline and small darkbrown blotches on its rays. Pectoral fin with interradial skin dark brown, in most specimens its blotches usually expand from rays to interradial skin, mainly on branched portion. Pelvic fin hyaline in most of proximal and medial regions, becoming darker at its branched portion. Dorsal fin with blotches from distal region of first two to four fin rays expanded and joined on interradial skin, forming singular vertical elongated blotch with wider upper region. Anal fin hyaline, with blotches on its distal region. Blotches from distal margin of caudal fin very expanded and joined over interradial skin, forming one or two wide bars occupying most of area. Caudal fin with darkish base. 


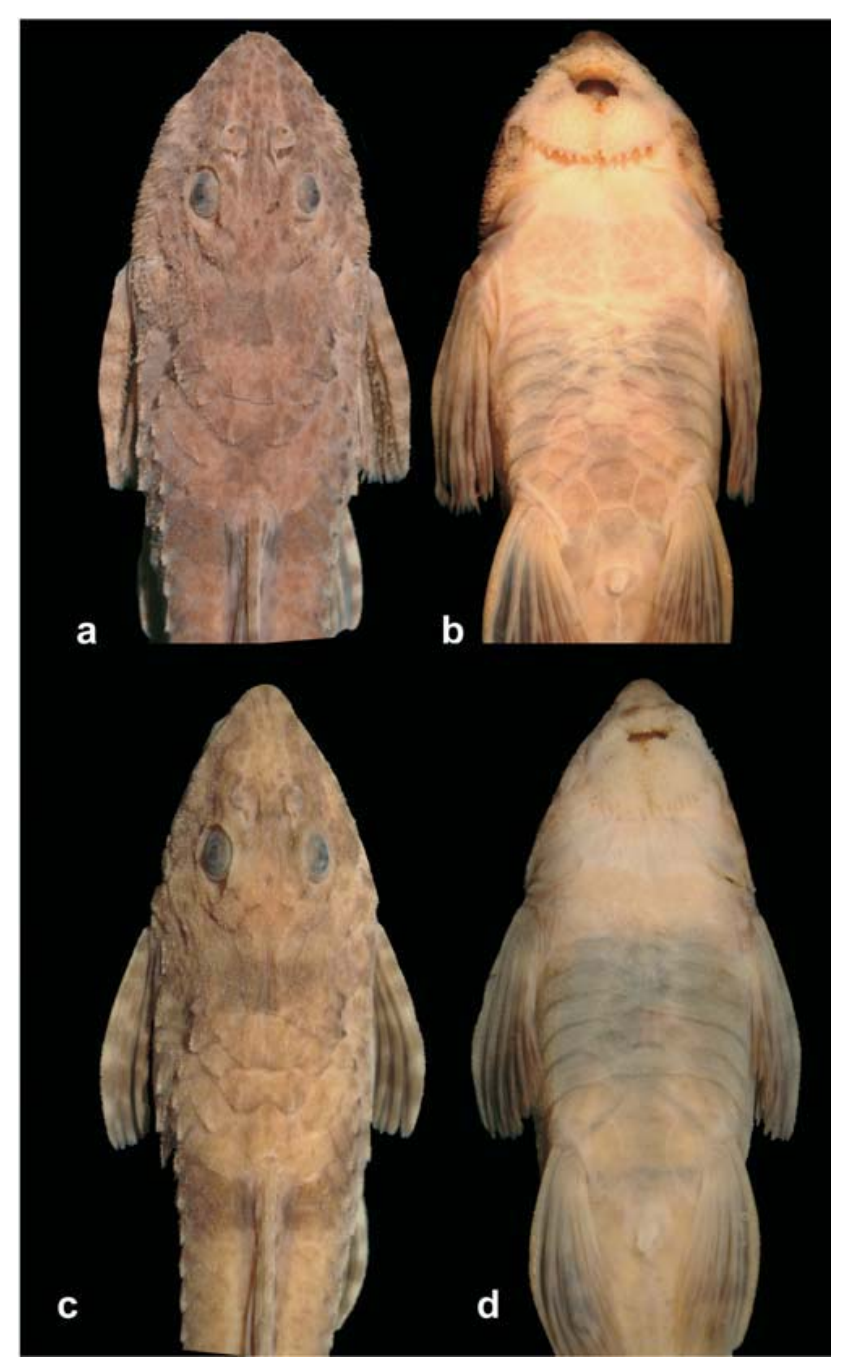

Fig. 2. Sexual dimorphism and plate distribution on abdomen and ventral region of pectoral girdle of Rineloricaria langei. a-b: holotype, male, MCP 42506, 114.9 mm SL; c-d: paratype, female, MCP 23459, 89.2 mm SL, rio Iraí, Quatro Barras, Paraná, Brazil.

Distribution and habitat. Rineloricaria langei is known from the rio Iraí (a headwater river of upper rio Iguaçu drainage), at the metropolitan region of Curitiba, Paraná State (Fig. 6). This species inhabits small streams with light to moderate streamflow, over a substrate of sand, some rocks and vegetal debris.

Etymology. The specific name langei is given in honor of Professor Rudolf Bruno Lange, one of the first curators of the zoological collections of Museu de História Natural Capão da Imbuia (MHNCI) during the forties of the Twentieth Century, in which the ichthyological collection is included.

Remarks. The paratypes MHNCI 8937 and MNRJ 31157 exhibit an artificial green color, easily seen on ventral surface of
Table 1. Morphometric data of Rineloricaria langei from upper rio Iguaçu. $\mathrm{N}=$ sample size; $\mathrm{SD}=$ Standard deviation. Range includes holotype.

\begin{tabular}{lcccccc}
\hline \multicolumn{1}{c}{ Variable } & N & Holotype & Low & High & Mean & SD \\
\hline Standard length (mm) & 20 & 114.9 & 51.7 & 116.5 & 90.9 & 16.0 \\
& Percents of standard length & & & \\
Head length & 20 & 20.7 & 18.9 & 21.0 & 19.9 & 0.7 \\
Predorsal length & 20 & 29.9 & 27.1 & 31.2 & 28.9 & 1.2 \\
Dorsal-spine length & 20 & 20.1 & 18.3 & 22.2 & 19.9 & 1.0 \\
Anal-spine length & 17 & 16.4 & 14.7 & 19.1 & 16.0 & 1.1 \\
Pectoral-spine length & 20 & 15.8 & 13.8 & 16.1 & 14.9 & 0.6 \\
Pelvic spine length & 20 & 13.6 & 12.2 & 14.1 & 13.2 & 0.6 \\
Dorsal caudal-spine length & 18 & 14.3 & 12.1 & 15.1 & 13.8 & 0.9 \\
Ventral caudal-spine length & 12 & - & 10.1 & 13.9 & 12.1 & 0.9 \\
Thoracic length & 20 & 13.2 & 11.8 & 14.1 & 13.0 & 0.7 \\
Abdominal length & 20 & 15.3 & 13.1 & 16.0 & 14.7 & 0.8 \\
Cleithral width & 20 & 15.7 & 13.0 & 15.7 & 14.1 & 0.7 \\
Body depth at dorsal-fin origin & 20 & 9.7 & 6.6 & 9.7 & 8.0 & 0.7 \\
Body width at anal-fin origin & 20 & 10.4 & 7.4 & 10.4 & 9.1 & 0.7 \\
Postanal length & 20 & 57.4 & 55.5 & 61.4 & 58.7 & 1.7 \\
& Percents of head length & & & \\
Snout length & 20 & 49.5 & 45.1 & 49.5 & 47.3 & 1.1 \\
Orbital diameter & 20 & 22.4 & 21.1 & 25.4 & 23.0 & 1.3 \\
Interorbital width & 20 & 21.8 & 19.7 & 24.0 & 21.5 & 1.0 \\
Head depth & 20 & 43.2 & 37.3 & 43.2 & 39.6 & 1.4 \\
Premaxillary ramus & 20 & 7.6 & 6.1 & 8.2 & 7.1 & 0.6 \\
Maxillary-barbel length & 19 & 10.1 & 7.9 & 13.6 & 10.3 & 1.3 \\
\hline
\end{tabular}

the specimens. That unnatural coloration was caused by an artifact during process of fixation and/or preservation in alcohol.

\section{Rineloricaria maacki, new species Figs. 3-5}

Holotype. MNRJ 31158, male, 108.4 mm SL, Brazil, Paraná, União da Vitória, rio Iguaçu, 51 $10^{\circ} 31^{\prime \prime} \mathrm{W} 26^{\circ} 10^{\prime} 16^{\prime}$ 'S, 25 May 2003, G. Otto.

Paratypes. MHNCI 11457, 2 ( 1 male, 1 female), 113.0-128.0 mm SL, collected with the holotype. MHNCI 11455, 1 (female), 102.8 $\mathrm{mm} \mathrm{SL}$, Brazil, Paraná, Lapa, areal Água Azul, rio Iguaçu, $50^{\circ} 11 ' 34^{\prime \prime} \mathrm{W} 25^{\circ} 47^{\prime} 34^{\prime \prime} \mathrm{S}, 22$ Feb 2001, L. F. Duboc, L. F. S. Ingenito \& F. Wegbecher. MHNCI 11682, 1 (female), 79.7 mm SL, Brazil, Paraná, Lapa, areal Água Azul, rio Iguaçu, 50¹1’34”'W 2547’34”S, 10 Nov 2000, L. F. Duboc \& L. F. S. Ingenito. NUP 2540, 3 (1 male, 1 female, 1 c\&s female), 110.8-133.5 mm SL, Brazil, Paraná, Cruz Machado/Bituruna, Foz do Areia rerservoir, rio Iguaçu, approx. $51^{\circ} 37^{\prime} \mathrm{W} 26^{\circ} 00^{\prime} \mathrm{S}, 26$ Oct 1998, NUPELIA. NUP 3059, 1 (male), 136.2 mm SL, Brazil, Paraná, Cruz Machado/Bituruna, Foz do Areia reservoir, rio Iguaçu, approx. $51^{\circ} 37^{\prime} \mathrm{W} 26^{\circ} 00^{\prime} \mathrm{S}, 6$ Oct 1999, COPEL.

Diagnosis. Rineloricaria maacki is easily distinguished from all Rineloricaria species except from $R$. latirostris, $R$. microlepidogaster, $R$. misionera, $R$. baliola, $R$. tropeira, and $R$. anhaguapitan by having a naked pectoral girdle and the abdomen covered by plates ( $v s$. pectoral girdle and abdomen completely covered by plates). In addition, the complete covering of plates of the abdominal region of Rineloricaria maacki distinguish it from $R$. setepovos (that has the abdo- 


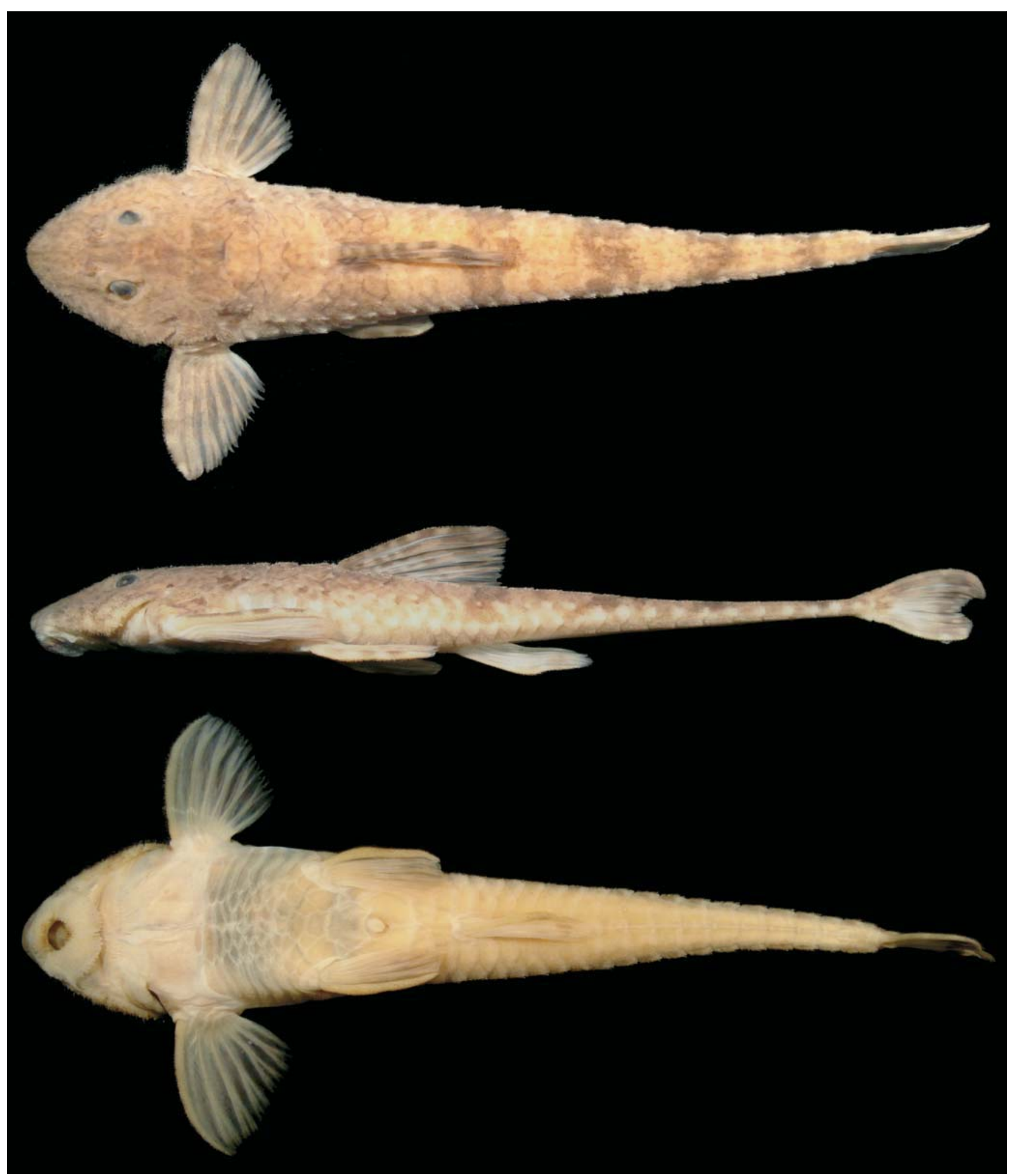

Fig. 3. Rineloricaria maacki, holotype, male, MNRJ 31158, 108.4 mm SL, rio Iguaçu, União da Vitória, Paraná, Brazil.

men naked); from $R$. aequalicuspis, $R$. maquinensis, and $R$. malabarbai (that have the abdomen variably covered, sometimes naked); and from $R$. reisi (that has the abdomen almost naked with few irregular platelets). Rineloricaria maacki can be distinguished from $R$. latirostris by the presence of five dorsal transverse bands (vs. six bands) and by having the dorsal unbranched caudal-fin ray not prolonged ( $v s$. dorsal unbranched caudal-fin ray produced as a long filament); from $R$. misionera, it is distinguished by having the pectoral girdle completely naked ( $v s$. pectoral girdle with, a few small, well- 


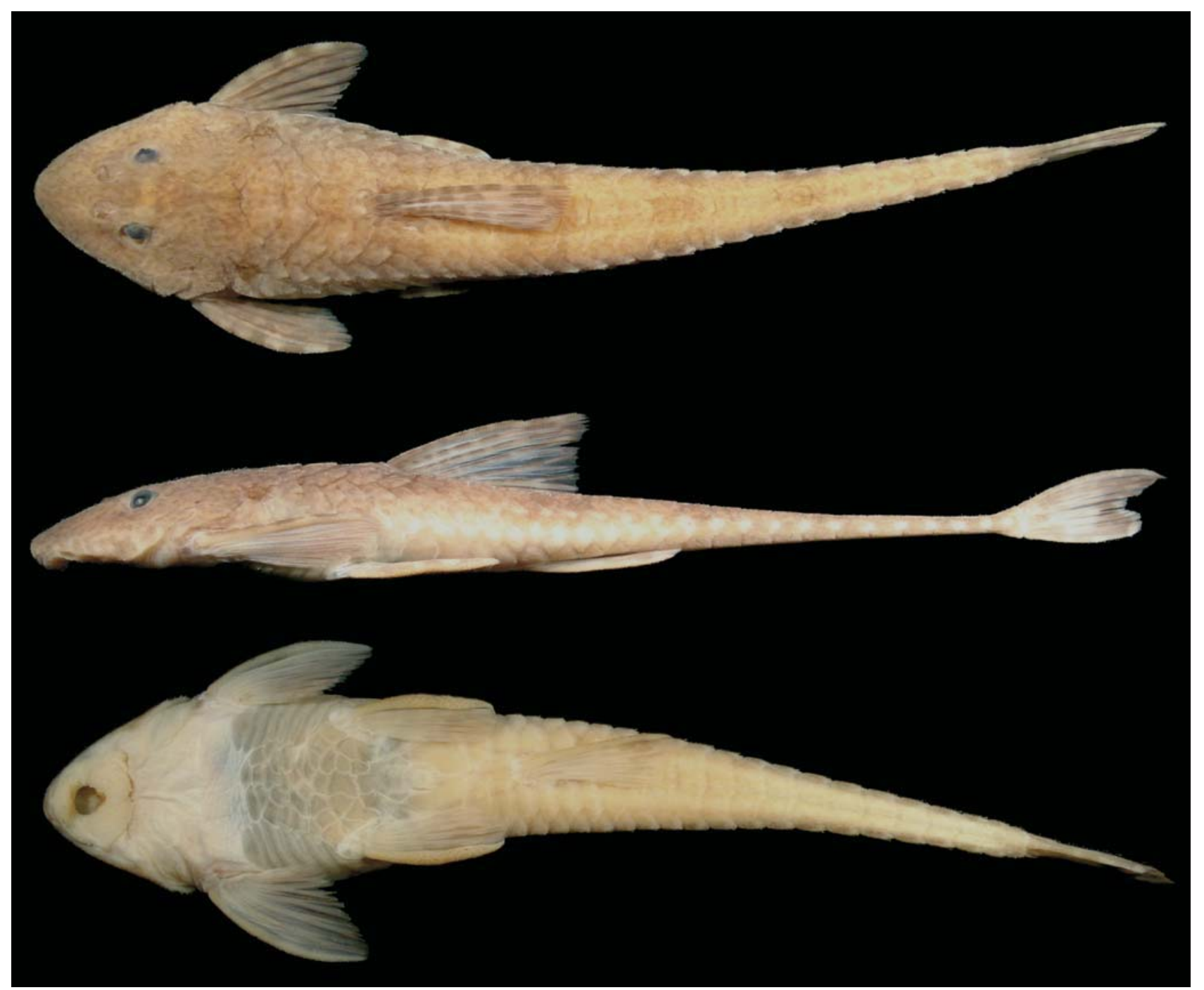

Fig. 4. Rineloricaria maacki, paratype, female, MHNCI 11457, 113.00 mm SL, rio Iguaçu, União da Vitória, Paraná, Brazil.

defined lateral plates). It can be distinguished from both $R$. anhaguapitan and $R$. baliola by its snout having a naked area not reaching to anterior most pore of infraorbital ramus of sensory canal species ( $v s$. snout with a naked area reaching to anterior most pore of infraorbital ramus of sensory canal) and by having all fins, except the dorsal fin, without a distal dark band ( $v s$. wide dark band covering the distal onehalf of all fins in $R$. baliola and the same color pattern on dorsal, anal and caudal fins in $R$. anhaguapitan); and from $R$. microlepidogaster, by having abdominal plates between lateral abdominal bones arranged in four ( $v s$. five to six) series and larger than abdominal plates of this species. Furthermore, $R$. maacki can be distinguished from $R$. microlepidogaster by having the pectoral fin usually not reaching the pelvic-fin origin ( $v s$. pectoral fin surpassing pelvic-fin origin).
Description. Morphometric data in Table 2. Head and body deeply depressed. Body depth greatest at dorsal-fin origin. Head triangular in dorsal view. Dorsal profile slightly convex from the tip of the snout to dorsal-fin origin, thereafter gradually depressed up to caudal-fin base. Ventral profile of body nearly straight from snout tip to anal-fin origin, then becoming more depressed towards caudal-fin base. Caudal peduncle depressed forming lateral keels with $11(3 *), 12$ (4) or 13 (2) coalesced plates from $28(1), 29\left(4^{*}\right)$ or $30(4)$ total lateral plates in middle series. Five lateral series of plates, mid-dorsal series present. Scapular bridge completely naked. Abdomen completely covered by plates. Four series of abdominal plates irregularly distributed. Pre-anal plate present and anteriorly rounded by three polygonal plates. Lateral abdominal plates four $\left(3^{*}\right)$, five (3) or six (3). Dorsal-fin base with five plate rows. Anal-fin base with two $(2)$ or three $\left(7^{*}\right)$ plate rows. Two 
(2) or three $\left(7^{*}\right)$ rows of plates between urogenital pore and anal fin. Plate counts on opposite sides of body usually different, except at dorsal- and anal-fin bases.

Top of head and parieto-supraocciptal smooth. Ridges of parieto-supraocciptal slightly divergent posteriorly. Plates of first three mid-dorsal series without evident ridges, almost smooth. Upper edge of orbit low. Postorbital notch with variable deep, short and narrow, not surpassing one third of the orbital diameter.

Head and body covered by very small odontodes, making fish somewhat smooth. Mature males with small hypertrophied odontodes distributes only on lateral margins of the head and weakly on dorsum of pectoral fin (Fig. 5). Snout tip with wide naked area, not reaching last pore of infra-orbital ramus of sensory canal. Snout tip ventraly naked, without odontodes between it and upper lip. Lips well developed and covered by papillae; only one irregular papillae row at anterior most area of the upper lip. Two rows of inconspicuous papillae separating upper and lower lips. Maxillary barbel thin and shorter than orbital diameter. Notch present in lower lip. Teeth bicuspid with lateral cusp smallest than medial. Premaxilla with five (2*), six (1), seven (3) or eight (3) teeth. Dentary with five (2), six (1), seven (1) or eight $\left(5^{*}\right)$ teeth. Total number of vertebrae 32. Five ribs attached to vertebrae 7 to 11 .

Pectoral-fins rays seven $(i, 6)$; fin margin sometimes reaching pelvic-fin origin when adpressed. Pelvic-fin rays six $(i, 5)$. Dorsal-fin rays eight $(i, 7)$; first ray shorter than head lenght; its origin located dorsal of pelvic-fins base. Anal-fin rays six (i,5). Caudal-fin rays 12 (i,10,i); its distal margin slightly concave; dorsal principal rays longer than ventral rays; in two

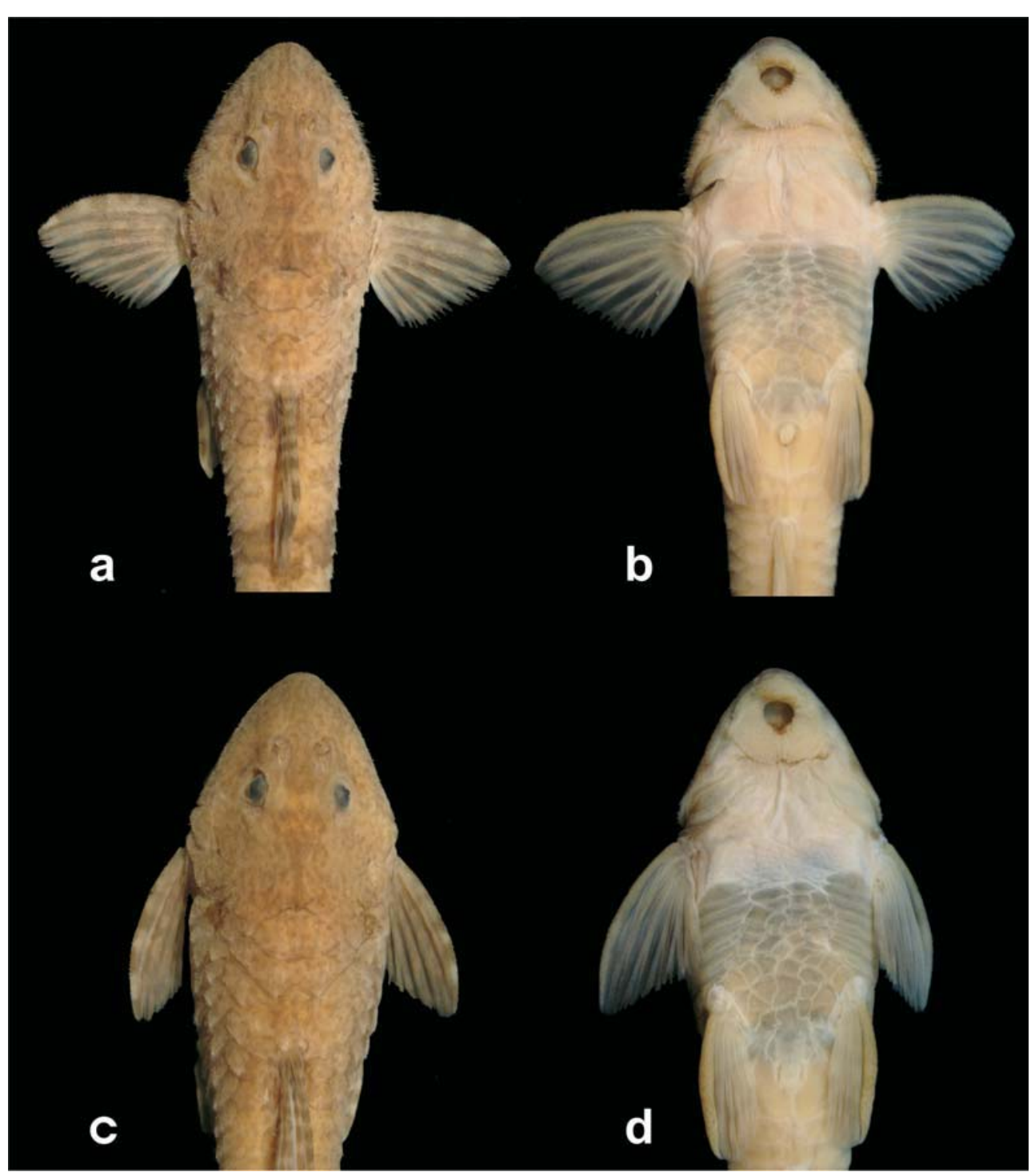

Fig. 5. Sexual dimorphism and plate distribution on abdomen and ventral region of pectoral girdle of Rineloricaria maacki. ab: holotype, male, MNRJ 31158, 108.4 mm SL; c-d: paratype, female, MHNCI 11457, 113.00 mm SL. 
specimens dorsal unbranched ray slightly elongated, extending distally less than one-third of orbital diameter and not prolonged as filament.

Color in alcohol. Ground color of dorsal surface light brown with darker small spots or vermiculated lines. Parietosupraocciptal dark brown. Five dark brown transverse bars across body; first on dorsal-fin origin, second on distal margin of dorsal-fin rays, third near vertical line surpassing through tip of anal-fin rays, fourth and fifth over caudal peduncle. Pores of laterosensory system without evident dark chromatophores. Ventral surface of the body pale or yellowish.

Fins yellowish with interradial skin hyaline and small darkbrown blotches on its rays. Blotches of distal margin of caudal fin very expanded and jointed over interradial skin, forming one bar occupying only its distal third. Caudal fin with darkish base.

Distribution and habitat. Rineloricaria maacki is known from middle and lower rio Iguaçu, a tributary of the rio Paraná basin (Fig. 6). This species inhabits the main channel and tributaries of rio Iguaçu, which has light brown muddy water with medium to fast flow over a sandy bottom. The habitat has little or no marginal vegetation, mainly formed by grass or bushes.

Etymology. The specific name maacki is given in honor of Reinhard Maack, a geologist who made some of the most important contributions to the knowledge of the geology and physiography of the rio Iguaçu basin and Paraná State.

\section{Discussion}

The rio Iguaçu is the last large left-bank tributary of rio Paraná. Its basin extends through a total area about 72,000 $\mathrm{km}^{2}$ occupying the States of Paraná and Santa Catarina in
Table 2. Morphometric data of Rineloricaria maacki from middle and lower rio Iguaçu. $\mathrm{N}=$ sample size; $\mathrm{SD}=$ Standard deviation. Range includes the holotype.

\begin{tabular}{lcccccc}
\hline \multicolumn{1}{c}{ Variable } & N & Holotype & Low & High & Mean & SD \\
\hline Standard length (mm) & 9 & 108.4 & 79.7 & 136.2 & 115.0 & 17.6 \\
& Percents of standard length & & & \\
Head length & 9 & 26.0 & 23.1 & 26.0 & 24.2 & 1.1 \\
Predorsal length & 9 & 36.2 & 32.6 & 37.4 & 34.8 & 1.5 \\
Dorsal spine length & 9 & 19.4 & 19.0 & 21.0 & 20.0 & 0.7 \\
Anal spine length & 9 & 15.1 & 13.9 & 16.8 & 15.5 & 1.0 \\
Pectoral spine length & 9 & 17.2 & 14.8 & 19.0 & 17.5 & 1.3 \\
Pelvic spine length & 9 & 14.3 & 13.5 & 16.2 & 14.7 & 0.8 \\
Upper caudal spine length & 9 & 14.7 & 13.9 & 17.2 & 15.5 & 1.1 \\
Lower caudal spine length & 9 & 11.7 & 11.0 & 13.8 & 12.2 & 0.8 \\
Thoracic length & 9 & 16.5 & 13.2 & 16.9 & 15.4 & 1.3 \\
Abdominal length & 9 & 17.6 & 15.6 & 18.2 & 16.8 & 0.9 \\
Cleithral width & 9 & 20.6 & 18.8 & 20.9 & 20.0 & 0.7 \\
Body depth at dorsal-fin origin & 9 & 9.4 & 9.4 & 13.0 & 10.7 & 1.2 \\
Body width at anal-fin origin & 9 & 12.1 & 11.3 & 12.6 & 12.0 & 0.4 \\
Postanal length & 9 & 50.2 & 50.2 & 54.0 & 51.8 & 1.3 \\
& Percents of head length & & & \\
Snout length & 9 & 46.9 & 46.9 & 52.2 & 49.6 & 1.4 \\
Orbital diameter & 9 & 21.1 & 19.4 & 21.9 & 21.0 & 0.7 \\
Interorbital width & 9 & 23.0 & 23.0 & 26.0 & 24.3 & 0.9 \\
Head depth & 9 & 35.5 & 35.5 & 43.9 & 40.0 & 2.7 \\
Premaxillary ramus & 9 & 6.7 & 6.3 & 7.7 & 7.0 & 0.5 \\
Maxillary barbel length & 9 & 4.0 & 3.4 & 7.0 & 4.5 & 1.2 \\
\hline \multicolumn{7}{c}{} \\
\hline
\end{tabular}

southern Brazil, and the province of Misiones in Argentina (Maack, 2002). The ichthyofauna of rio Iguaçu includes about 83 species (Ingenito et al., 2004; present study) and a high level of endemism, with a rate of about $75 \%$ of exclusive species (Zawadzki et al., 1999).

Reis \& Cardoso (2001) were the first authors to report the presence of species of Rineloricaria in the rio Iguaçu basin, when they cited the presence of one or two undescribed species. Recent studies conducted by us revealed the existence of four possibly undescribed species of Rineloricaria at this basin. Two of those species are Rineloricaria maacki and Rineloricaria langei, which are described here. As for the other two undescribed species, we did not have success in

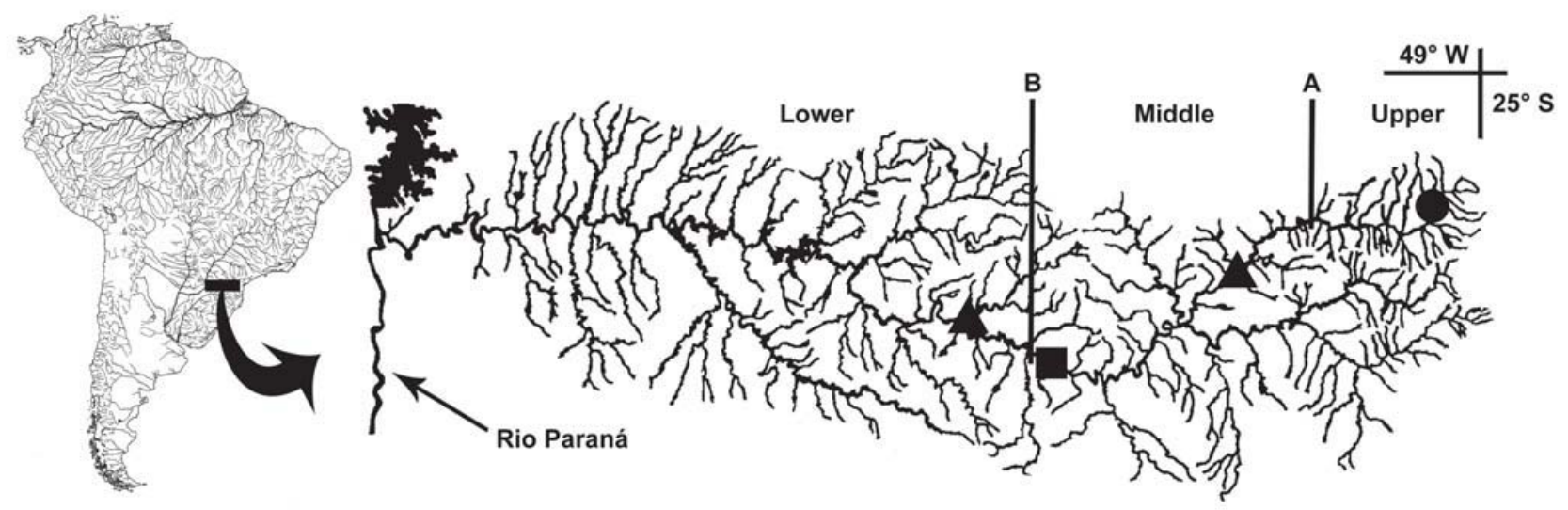

Fig. 6. Distribution of Rineloricaria langei (circle) and Rineloricaria maacki (square: holotype; triangles: paratypes) in rio Iguaçu basin. One symbol may represent more than one collecting locality. Vertical bars indicate biogeographic barriers of rio Iguaçu according to Ingenito et al. (2004) (A: Salto Caiacanga falls; B: Salto Grande falls). 
finding consistent diagnostic characters to describe them. Those two species can only be assigned at present to a generic description of Rineloricaria lima, which is taxonomically problematic (see below).

The specimens mentioned by Reis \& Cardoso (2001) were not available for examination during the present study. However, information provided by Wolmar B. Wosiacki (MPEG) indicates that the lot MCP 17455 examined by those authors is composed by at least one of the two new species assigned as Rineloricaria sp. aff. lima by us. This species was also cited by Vitule \& Abilhoa (2003) for rio Piraquara (a headwater river of the rio Iguaçu basin), and it was part of a series of specimens cited by Ingenito et al. (2004) for upper Iguaçu basin (MHNCI 9133 and MHNCI 9212). The fishes assigned here to Rineloricaria sp. aff. lima are widely distributed in the river basins rio Piraquara, rio Negro and rio da Várzea, and are sympatric to $R$. langei in the rio Iraí. Moreover, comparisons carried out by us with Rineloricaria specimens from coastal drainages indicate that Rineloricaria sp. aff. lima seems to be widely distributed along the coastal drainages of Paraná State, where it is found with a new species under description by us, which is characterized by having a short body and naked thoracic and abdominal regions.

Rineloricaria lima, the type species of the genus, was collected by Johann Natterer from "Brazilian rivers" during the 18 years that he lived in Brazil (1817-1835) (Riedl-Dorn, 2000; Vanzolini, 2004). The type specimen of $R$. lima has been lost and the original description, which was based on a dry specimen, is poor and characterizes most of species of the genus. With the loss of the type specimen of $R$. lima (Isbrücker, 1979), and the extensive nature of Natterer's travels (including the Amazon basin, rio Paraguay, rio Paraná, rio Paraíba do Sul, and to the cities of Curitiba (rio Iguaçu) and Paranaguá (coastal Atlantic drainages of Paraná State)), it is not easy to associate any specimen to this name until the designation of a neotype, what is beyond the scope of this paper.

The absence of ventral plates observed in $R$. maacki is widely variable among loricarids, but among species of Rineloricaria sensu lato this character is restricted to species from the rio Paraná basin ( $R$. latirostris, $R$. maacki), rio Uruguay ( $R$. misionera, $R$. setepovos, $R$. anhaguapitan, $R$. reisi, $R$. capitonia, and $R$. tropeira) and coastal drainages from southeastern and southern Brazil (R. aequalicuspis, $R$. maquinensis, $R$. malabarbai, $R$. baliola, $R$. microlepidogaster, and an undescribed species from Rio de Janeiro State). This character is not exclusive to Rineloricaria but can be an indicative of common ancestry between some species from geographical range cited above, as suggested by Ghazzi (2008), and proposed by Isbrücker et al. (2001), Ferraris (2007), and Rodriguez \& Reis (2008). However, such a hypothesis requires a phylogenetic analysis of the members of Rineloricaria, what is also beyond the scope of the present study. The distribution of Rineloricaria species having a naked ventral area may also indicate close biogeographic re- lationship among Paraná and coastal Atlantic drainages through rio Iguaçu, that strengthens the hypotheses of Ingenito et al. (2004) and Torres et al. (2008). Such hypotheses also may explain the morphological similarities among $R$. lange $i$ and $R$. quadrensis.

The species herein described do not corroborate the statement proposed by Rodriguez \& Reis (2008), who recognized two ecomorphological groups of Rineloricaria inhabiting sandy or rocky habitats. Both $R$. langei and $R$. maacki inhabit mostly sandy environments. However, the two new species have the naked area of the tip of snout not reaching the most anterior pore of the infraorbital ramus of sensory canal, which was reported to be a characteristic of the "rocky group" according to Rodriguez \& Reis (2008). Such incongruence also occurs in some of the species assigned by those authors to the "sandy group" (e. g. R. kronei, R. misionera, $R$. quadrensis, $R$. steindachneri, and $R$. strigilata). Moreover, the presence of the mid-dorsal series of lateral plates in R. maacki, a character of the "rocky group", also contradicts those authors' statement. The variation evidenced here may indicate that such characters are not informative to distinguish the "sandy" and "rocky" species groups, or that the morphological characters proposed by Rodriguez \& Reis (2008) are not associated to specific habitats.

\section{Acknowledgments}

This paper was benefited from comments and criticisms from M. Rodriguez (MLP, LIRP), and revision of English language from S. C. Ehlers (Fiocruz). For the loan of specimens, and other assistance during visits to institutions, we are indebted to F. Meyer (MAPA), M. Rodriguez (MLP), Z. M. Lucena and R. E. Reis (MCP), J. L. de Figueiredo and O. T. Oyakawa (MZUSP), H. Wellendorf (NMW), C. S. Pavanelli (NUP), L. R. Malabarba (UFRGS). We are grateful to W. B. Wosiacki (MPEG) for the informations about the lots from MCP and MHNCI on loan to him. This study was supported by grants from Conselho Nacional de Desenvolvimento Científico e Tecnológico (CNPq, 474788/2006-7 and 502975/ 2005-9 to MNRJ; post-doctoral fellowship to M. S. Ghazzi), and Coordenação de Aperfeiçoamento de Pessoal de Nível Superior (CAPES, doctoral fellowship to L. F. S. Ingenito).

Comparative material. Hemiloricaria cacerensis: Brazil: Mato Grosso: rio Paraguai drainage: MNRJ 645 (3 syntypes). Hemiloricaria hoehnei: Brazil: Mato Grosso: rio Paraguai: MNRJ 650 (holotype). Hemiloricaria lanceolata: Brazil: Rondônia: rio Madeira drainage: MNRJ 14972 (35). Hemiloricaria parva: Brazil: Mato Grosso: bacia do rio Paraguai: MCP 15703 (5); Paraguay: Central: bacia do rio Paraguai: MNRJ 23315 (2), MNRJ 23316 (6). Rineloricaria aequalicuspis: Brazil: Rio Grande do Sul: rio Três Forquilhas: MCP 10795 (24 paratypes); Santa Catarina: rio Araranguá: MCP 10618 (25), MZUSP 37707 (4). Rineloricaria anhaguapitan: Brazil: Rio Grande do Sul: rio Uruguay drainage: MCP 21070 (holotype). Rineloricaria anitae: Brazil: Santa Catarina: rio Uruguay drainage: MCP 19685 (holotype). 
Rineloricaria baliola: Brazil: Rio Grande do Sul: rio Jacuí drainage: MCP 1329 (7), MCP 1270 (3). Rineloricaria cadeae: Brazil: Rio Grande do Sul: laguna dos Patos drainage: MCP 11108 (15), MCP 9727 (6); rio Jacuí drainage: MCP 17499 (6), MCP 19431 (12). Rineloricaria capitonia: Brazil: Rio Grande do Sul: rio Uruguay drainage: MCP 19687 (holotype). Rineloricaria catamarcensis: Argentina: Tucumán: río Salí: FML 069 (1). Rineloricaria felipponei: Uruguay: Canelones: río Santa Lucía: ANSP 70324 (holotype). Rineloricaria jaraguensis: Brazil: Santa Catarina: Jaraguá (= rio Itapocu): NMW 44886 (lectotype designated by Isbrucker, 1979:113), NMW 44883 (1 paralectotype); rio Piraí: MZUSP 24579 (10). Rineloricaria kronei: Brazil: São Paulo: rio Ribeira de Iguape drainage: MZUSP 58889 (4), MZUSP 60228 (8). Rineloricaria latirostris: Brazil: Mato Grosso do Sul: rio Paraná drainage: MZUSP 24447 (15); São Paulo: rio Paraná drainage: MZUSP 3107 (10 of 20), MZUSP 22742 (3), MZUSP 83672 (6), MZUSP 22471 (1), MZUSP 23072 (3 of 16), MZUSP 24979 (4), MZUSP 24979 (4), MZUSP 22641 (3), MZUSP 62418 (1). Rineloricaria longicauda: Brazil: Rio Grande do Sul: Banhado do Taim: MZUSP 16078 (holotype), MAPA 1337 (1 paratype), MAPA 1338 (1 paratype), MAPA 1339 (1 paratype), MAPA 1333 (1 paratype), UFRGS 574 (1 paratype). Rineloricaria malabarbai: Brazil: Rio Grande do Sul: rio dos Sinos: MAPA 1261 (3 paratypes). Rineloricaria maquinensis: Brazil: Rio Grande do Sul: rio Maquiné: MZUSP 27347 (1 paratype), MAPA 1258 (2 paratype), MCP 10769 (14 paratype); Santa Catarina: rio Araranguá: MCP 10622 (6). Rineloricaria microlepidogaster: Brazil: Rio Grande do Sul: Lagoa dos Patos drainage: MCP 17234 (1), MNRJ 22232 (1); Rio Jacuí: MCP 17251 (2); Rio Jaguarão: MCP 11266 (1). Rineloricaria misionera: Argentina: Misiones: MCP 35793 (3 paratypes). Rineloricaria nigricauda: Brazil: Rio de Janeiro: rio Paraíba do Sul: BMNH 1891.6.16.32 (lectotype designated by Isbrucker, 1979: 113), MNRJ 14017 (20), MNRJ 13955 (29). Rineloricaria pareiacantha: Uruguay: Canelones: río Santa Lucía: ANSP 67815 (holotype). Rineloricaria pentamaculata: Brazil: São Paulo: rio Paraná drainage: MZUSP 43501 (holotype), MZUSP 43502 (paratype), MZUSP 43503 (2 paratypes); Minas Gerais: rio Paraná drainage: MZUSP 38892 (2 paratypes); Goiás: rio Paraná drainage: MNRJ 26390 (1), MNRJ 26391 (1). Rineloricaria quadrensis: Brazil: Rio Grande do Sul: lagoa dos Quadros drainage: MCP 15268 (4), MCP 9548 (4), MCP 13598 (3). Rineloricaria reisi: Brazil: Rio Grande do Sul: rio Uruguay drainage: MZUSP 28748 (holotype). Rineloricaria sanga: Brazil: Rio Grande do Sul: rio Uruguay drainage: MCP 19686 (holotype). Rineloricaria setepovos: Brazil: Rio Grande do Sul: rio Uruguay drainage: MCP 19680 (holotype). Rineloricaria steindachneri: Brazil: Rio de Janeiro: rio Paraíba do Sul drainage: NMW 45016:1 (lectotype designated by Isbrucker, 1979:113), NMW 45013 (2 paralectotypes), MNRJ 13375 (4), MNRJ 14007 (10). Rineloricaria stellata: Brazil: Rio Grande do Sul: rio Uruguay drainage: MCP 19682 (holotype). Rineloricaria strigilata: Brazil: Rio Grande do Sul: rio Jacuí drainage: MCP 9787 (16), MCP 14176 (12), MCP 19433 (2). Rineloricaria thrissoceps: Uruguay: Canelones: río Santa Lucía: ANSP 67796 (holotype). Rineloricaria tropeira: Brazil: Rio Grande do Sul: Rio Uruguay drainage: MCP 19684 (holotype). Rineloricaria zaina: Brazil: Rio Grande do Sul: rio Uruguay drainage: MCP 19683 (holotype). Rineloricaria aff. lima: Brazil: Paraná: rio Iguaçu drainage: rio Piraquara: MHNCI 11717 (20), MHNCI 9084 (1), MHNCI 9133 (6), MHNCI 9212 (3), MHNCI 9469 (10), MHNCI 10450 (2), MHNCI 11456 (3), MHNCI 11389 (7); rio Negro: MCP 11535 (2); rio da Várzea: MCP 23458 (1), MHNCI 8938 (2); coastal
Atlantic drainages: rio Morato drainage: MHNCI 11037 (5); rio Serra Negra drainage: MHNCI 6368 (5). Rineloricaria sp.: Brazil: Paraná: Rio Marumbi drainage: MHNCI 11040 (13); rio Nhundiaquara drainage: MHNCI 6576 (11); Rio de Janeiro: rio Macacu drainage: MNRJ 19621 (7).

\section{Literature Cited}

Covain, R. \& S. Fisch-Muller. 2007. The genera of the Neotropical armored catfish subfamily Loricariinae (Siluriformes: Loricariidae): a practical key and synopsis. Zootaxa, 1462: $1-40$.

Ferraris, C. J. 2003. Subfamily Loricariinae. Pp. 330-350. In: Check list of the freshwater fishes of South and Central America. R. E. Reis, S. O. Kullander \& C. J. Ferraris (eds.). Edipucrs, Porto Alegre, 729p.

Ferraris, C. J. 2007. Checklist of catfishes, recent and fossil (Osteichthyes: Siluriformes), and catalogue of siluriform primary types. Zootaxa, 1418: 1-628.

Flores-Lopes, F., L. R. Malabarba, E. H. L. Pereira \& J. Pezzi da Silva. 2001. Alterações histológicas em placas ósseas do peixe cascudo Rineloricaria strigilata (Hensel) (Teleostei: Loricariidae) e sua freqüência no lago Guaíba, Rio Grande do Sul, Brasil. Revista Brasileira de Zoologia, 18(3): 699709 .

Ghazzi, M. S. 2008. Nove espécies novas do gênero Rineloricaria (Siluriformes: Loricariidae) do rio Uruguai, do sul do Brasil. Iheringia, Série Zoologia, 98(1): 100-122.

Ingenito, L. F. S., L. F. Duboc \& V. Abilhoa. 2004. Contribuição ao conhecimento da ictiofauna da bacia do alto rio Iguaçu, Paraná, Brasil. Arquivos de Ciências Veterinárias e Zoologia da UNIPAR, 7(1): 23-36.

Isbrücker, I. J. H. 1979. Descriptions préliminaries de nouveaux taxa de la famille des Loricariidae, poissons-chats cuirassés néotropicaux, avec un catalogue critique de la sous-famille nominale (Pisces,Siluriformes). Revue française d'Aquariologie, 5(4): 86-117.

Isbrücker, I. J. H., I. Seidel, J. P. Michels, E. Schraml \& A. Werner. 2001. Diagnose vierzehn neuer Gatungen der Familie Loricariidae Rafinesque, 1815 (Teleostei, Ostariophysi). Die Aquarien und Terrarien Zeitschrift, Sonderheft Harnischwelse, 2: 17-24.

Kner, R. 1853. Die Panzerwelse des K. K. Hof-naturalienCabinetes zu Wien. I. Abtheilung. Loricarinae. Denkschriften Akademie der Wissenschaften in Wien, 6: 65-98.

Maack, R. 2002. Geografia física do Estado do Paraná. $3^{\text {a }}$ edição. Curitiba, Imprensa Oficial, 440p.

Regan, C. T. 1904. A monograph of the fishes of the family Loricariidae. Transactions of the Zoological Society of London, 17(1), part 3: 191-350.

Reis, R. E. \& A. R. Cardoso. 2001. Two new species of Rineloricaria from southern Santa Catarina and northeastern Rio Grande do Sul, Brazil (Teleostei: Loricariidae). Ichthyological Exploration of Freshwaters, 10(1): 45-51. 
Riedl-Dorn, C. (Org.). 2000. Johann Natterer e a missão austríaca para o Brasil. Petrópolis, Ed. Index, 192p.

Rodriguez, M. S. \& A. M. Miquelarena. 2005. A new species of Rineloricaria (Siluriformes: Loricariidae) from the Paraná and Uruguay river basins, Misiones, Argentina. Zootaxa, 945: 1-15.

Rodriguez, M. S. \& R. E. Reis. 2008. Taxonomic review of Rineloricaria (Loricariidae: Loricariinae) from the laguna dos Patos drainage, Southern Brazil, with the descriptions of two new species and the recognition of two species groups. Copeia, 2008(2): 333-349.

Schaefer, S. A. 1997. The neotropical cascudinhos: systematics and biogeography of the Otocinclus catfishes (Siluriformes, Loricariidae). Proceedings of the Academy of Natural Sciences of Philadelphia, 148: 1-120.

Taylor, W. R. \& G. C. Van Dyke. 1985. Revised procedures for staining and clearing small fishes and other vertebrates for bone and cartilage study. Cybium, 9: 107-119.

Torres, R. A., T. S. Motta, D. Nardino, M. L. Adam \& J. Ribeiro. 2008. Chromosomes, RAPDs and evolutionary trends of the Neotropical fish Mimagoniates microlepis (Teleostei: Characidae: Glandulocaudinae) from coastal and continental regions of the Atlantic forest, Southern Brazil. Acta Zoologica, 89: 253-259.

Vanzolini, P. E. 2004. Episódios da zoologia brasílica. Hucitec, São Paulo, 212p.

Vitule, J. R. S. \& V. Abilhoa. 2003. A composição da ictiofauna na bacia hidrográfica do rio Piraquara, alto rio Iguaçu, Região Metropolitana de Curitiba, Paraná, Brasil. Estudos de Biologia, 25(52): 43-49.

Zawadzki, C. H., E. Renesto \& L. M. Bini. 1999. Genetic and morphometric analisis of three species of the genus $\mathrm{Hy}$ postomus Lacépède, 1803 (Osteichthyes: Loricariidae) from the rio Iguaçu basin (Brazil). Revue suisse de Zoologie, 106: 91-105.

Accepted August, 2008 Published September 30, 2008 